\title{
Improvement Quality and Shelf Life Assessment of Minimally Processed Apples by Use of Protein Coatings
}

\author{
Sandriane Pizato ${ }^{1}$, William Renzo Cortez-Vega ${ }^{2}$, Tailine Saturnino Da Costa ${ }^{2}$, Lauren Menegon de Oliveira ${ }^{1} \&$ \\ Carlos Prentice ${ }^{1}$ \\ ${ }^{1}$ Laboratory of Food Technology, School of Chemistry and Foods, Federal University of Rio Grande, Rio \\ Grande, RS, Brazil \\ ${ }^{2}$ Laboratory of Bioengineering, Faculty of Engineering, Federal University of Grande Dourados, Dourados, \\ Brazil \\ Correspondence: Sandriane Pizato, School of Chemistry and Foods, Federal University of Rio Grande, Rio \\ Grande, RS, Brazil. Tel: 55-53-3233-8621. E-mail: sandrianepizato@yahoo.com.br
}

Received: July 7, 2013 Accepted: July 30, 2013 Online Published: August 5, 2013

doi:10.5539/jfr.v2n5p24 URL: http://dx.doi.org/10.5539/jfr.v2n5p24

\begin{abstract}
Minimally processed fruits offer a convenient and practical product to the consumer, with quality and freshness similar to the in natura product. The aim of this study was to apply coatings of croaker protein isolate (Micropogonias furnieri) with organoclay (montmorillonite) on minimally processed apples during 12 days of storage at $5 \pm 1{ }^{\circ} \mathrm{C}$. The apples were washed, peeled and cut into cubes. Coatings were then applied where T1 (control sample), T2 (croaker protein isolate coating) and T3 (croaker protein isolate coating and montmorillonite (MMT). The pieces were allowed to drain into sieves and these were stored in polyethylene terephthalete (PET) packaging for a period of 12 days at $5 \pm 1{ }^{\circ} \mathrm{C}$. Analyses of weight loss, firmness, color (Lightness $\left(\mathrm{L}^{*}\right)$, Chroma $\mathrm{a}^{*}$ and $\left.\mathrm{b}^{*}\right), \mathrm{pH}$, and microbiological analyses (psychrotrophic, yeasts and molds, Salmonella and Escherichia coli) were carried out. The analyses were carried out in triplicate and evaluated at the times of 1,3,5, 7, 9 and 12 days of storage. The use of croaker protein isolate coating and MMT proved promising in keeping weight loss, microbiological counts, enzymatic browning and firmness loss at minimum in minimally processed apples.
\end{abstract}

Keywords: apples, MMT, croaker protein isolate, shelf life quality

\section{Introduction}

The apple is the fruit of the Pyrus malus tree, with thin and waterproof peel, bittersweet, acid or farinaceous flavor (depending on the species), and homogeneous pulp (Rizzon, Bernadi, \& Miele, 2005).

Minimally processed fruits offer a convenient and practical product to the consumer, with quality and freshness similar to the in natura product (Pizato, Cortez-Vega, Souza, Prentice-Hernández, \& Borges, 2013a).

The processing of apple represents a way of using surplus production, conserving and adding value to the product and, moreover, it provides the convenience of consumption. Fresh-cut vegetables must be kept fresh, although the cutting of the tissue accelerates enzymatic processes, since it decompartimentalizes cells and makes enzymes and substrates are in touch, causing harmful reactions to the quality of the product, especially the enzymatic browning and tissue softening (Vilas Boas, Reis, Melo, \& Martins, 2009). Among many fruits, peeled ready to eat has drawn the attention of food industry and research as a novel minimally processed product $(\mathrm{Li}, \mathrm{Li}$, Fan, Tang, \& Yun, 2012)

Quality and shelf life of fresh-cut fruits are reduced by water loss, senescence processes, microbial growth, colour and texture changes, due to the tissue injuries caused by peeling, slicing and cutting. Thus, in spite of their convenience, fresh-cut mangoes may show browning and undesirable texture changes during storage (Chiumarelli, Pereira, Ferrari, Sarantópoulos, \& Hubinger, 2010).

Edible coatings have been used as an alternative to reduce the effects caused by minimal processing. These are defined as a thin layer of edible material, applied and formed directly on the surface of the product. They are used to inhibit migration of moisture, oxygen, carbon dioxide, aromas, and lipids, and introduce additives such as antioxidants and antimicrobials, thereby improving the intrinsic characteristics, mechanical integrity, and 
handling of food products which are coated with this type of material (Krochta-Johnston \& Mulder, 1997). They are applied on cut apples to produce a modified atmosphere, which reduces decay, delays ripening and color changes, texture enhancers, nutraceuticals, flavor, and volatile precursors (Olivas, Mattinson, \& Barbosa-Cánovas, 2007).

The objective of this study was to apply edible coatings from protein isolate of Whitemouth croaker with organo-clay Montmorillonite in Fresh-Cut apple, throughout the storage of 12 days at $5 \pm 1{ }^{\circ} \mathrm{C}$, and assess their properties and verify the effectiveness of this coating as a barrier against the weight loss of apple, aiming to increase its shelf life.

\section{Material and Methods}

'Gala' apples (Malus domestica Borkh) were purchased in local shops in the city of Rio Grande/RS - Brazil at commercially maturity stage, based on external colour and firmness, physiological defect-free and visually detectable infections caused by microorganisms. Samples were transported in coolers to the laboratory where they were stored at $5 \pm 1{ }^{\circ} \mathrm{C}$ until processing. The croaker protein isolate (CPI) was obtained according to the adapted methodology of Nolsoe and Underland (2009) and Freitas, Gautério, Rios and Prentice (2011) to solubilize and isolate protein by the $\mathrm{pH}$ shifting process, as mechanically separated meat (MSM) from the industrialization of Whitemouth croaker (Micropogonias furnieri). The organophilic clay utilized was Montmorillonite K10 (Sigma-Aldrich) with a particle size of $10 \mathrm{~nm}$. The plasticizer used was glycerol (Vetec, Fine Chemicals).

\subsection{Preparation of Film Solution}

The film solution was prepared by the casting technique. The polymer coating was developed initially in the preparation of a dispersion of $35 \mathrm{~g}$ of CPI in distilled water in a beaker of $1000 \mathrm{ml}$. This aqueous dispersion was maintained with gentle and constant stirring for 20 minutes with a stirring propeller shaft (Fisatom, 713D) at $30{ }^{\circ} \mathrm{C}$ in thermostatic ultrasonic bath (QUIMIS, 214 D2), for hydration of the CPI. After the hydration, the dispersion $\mathrm{pH}$ was adjusted to 11.2 with the addition of $1 \mathrm{~N} \mathrm{NaOH}$ (Merck) using $\mathrm{pH}$ meter bench (Marconi, PA 200) while maintaining constant stirring for 10 minutes. Then $5 \mathrm{~g}$ of MMT were added and the temperature was elevated to $80^{\circ} \mathrm{C}$. After complete dissolution of the CPI and MMT $10.5 \mathrm{~g}$ of glycerol previously dissolved in distilled water at the temperature of the film solution $\left(80^{\circ} \mathrm{C}\right)$ was added maintaining the $\mathrm{pH}$ at 11.2 . Subsequently, the film solution was placed in homogenizer (Ultra-turrax IKA, T25) for 5 minutes. For the preparation of pure CPI coating, the same procedure was carried out without addition of MMT. Once the film solutions were prepared, these were used for coating Fresh-Cut apple.

\subsection{Preparation of Fresh-Cut Apple}

The minimally processing was performed at a temperature of about $10{ }^{\circ} \mathrm{C}$ with the previously sanitized utensils in a solution of organic chlorine (dichlorocyanurate) at the concentration of $2 \mathrm{~g}$. $\mathrm{L}^{-1}$. The selected apple was also cleaned with a solution of organic chlorine at the concentration of $2 \mathrm{~g}^{-1} \mathrm{~L}^{-1}$ for 5 minutes. The operators were properly protected with gloves, aprons, hats and masks, in order to protect the product, as much as possible, from contamination. The raw material was subjected to manual removal of the peel and seeds and afterwards it was manually cut into slices $(2.5 \times 2.5 \mathrm{~cm})$. Then, these slices were rinsed with chlorinated water $\left(0.2 \mathrm{~g} . \mathrm{L}^{-1}\right)$ to eliminate cellular spilled juice. Water was drained using sieves for a period of 2-3 minutes.

\subsection{Apple Coatings}

Dried and sanitized apple was divided into three lots: Treatment 1 (T1, control), Treatment 2 (T2, pure CPI coating) and Treatment 3 (T3, CPI coating with MMT). The T2 and T3 were immersed in a film solution for 5 minutes, they were then drained using sieves, and left to dry for 2-3 minutes.

The samples for each treatment were packaged in unrecycled PET (Polyethylene Terephthalate) containers, with cover (SANPACK), whose external dimensions were $15.5 \times 13.2 \times 5.5 \mathrm{~cm}$. The number of slices per package was standardized and stored in refrigerated conditions at $5 \pm 1{ }^{\circ} \mathrm{C}$.

\subsection{Physicochemical Analysis of Coated Apple}

The weight loss was obtained by taking the difference between the initial weight of the Fresh-Cut apple and that obtained one at the end of each storage time, according to the formula:

(\%) Weight loss $=[($ initial mass - final mass) $/$ (initial mass) $] \times 100$ (AOAC, 2000).

The results were expressed as percentage of weight loss. 
The measures of the Fresh-Cut apple slices firmness were determined by using a texture analyzer (Stable Micro Systems, TA.XT.plus). A cylindrical probe in the pre-test speed of $4 \mathrm{~mm} \cdot \mathrm{s}^{-1}$, post-test of $8 \mathrm{~mm} \cdot \mathrm{s}^{-1}$, test of $2 \mathrm{~mm} \cdot \mathrm{s}^{-1}$ and penetration depth of $5 \mathrm{~mm}$ was used. The results were expressed in Newton $(\mathrm{N})$.

Color analysis was evaluated by using a Minolta colorimeter, model Chroma Meter CR400. The parameters of lightness L* [0 (black) to 100 (white)], Chroma a* [green chromaticity (-60) to red (+60)] and Chroma $\mathrm{b}^{*}$ [blue chromaticity (-60) to yellow $(+60)]$ were verified (Pizato et al., 2013a).

The $\mathrm{pH}$ was determined by using the method described by AOAC (2000). The $\mathrm{pH}$ was measured using a digital $\mathrm{pH}$ meter (Marconi, PA 200). It was prepared a suspension of $20 \mathrm{~g}$ of sample in $100 \mathrm{~mL}$ of distilled water, thus measuring the $\mathrm{pH}$ with the assistance of a $\mathrm{pH}$ meter.

Sensory analysis was not performed.

\subsection{Microbiological Analysis of Coated Apple}

Microbiological tests performed were psychotrophic, moulds and yeasts, Escherichia coli, and Salmonella sp., following the methods described in APHA (2001).

\subsection{Statistical Analysis}

The results were analyzed statistically by the analysis of variance (ANOVA) using the software Statistica ${ }^{\circledR} 7.0$ (StatSoft, Inc., Tulsa, USA). Mean separation was determined using the Tukey test at $P \leq 0.05$.

\section{Results and Discussion}

\subsection{Physical Analysis}

\subsubsection{Weight Loss}

Weight loss is one of the main factors which are responsible for the reduced shelf life of fresh-cut vegetable. It occurs due to storage time and transpiration. Such loss has an effect on the physiology of the plant tissues and results in loss of efficiency, appearance, texture, and nutritional qualities (Carvalho \& Lima, 2002).

Table 1 shows the weight loss in samples of apples minimally processed apples using different coatings.

An increase in weight loss during storage was observed for all treatments as shown in Table 1.

The control sample (T1) showed the greatest increase in mass loss after 12 days of storage (8.2\%), followed by $\mathrm{T} 2$ and $\mathrm{T} 3(5.7$ and $4.2 \%)$ respectively.

It can be observed that there was no significant difference between the treatments analyzed only on the first day of storage, and during the other days, the treatments differed from each other.

Olivas et al. (2007) evaluated the weight loss on samples of fresh cut apples coated with alginate and stored for 10 days at $5{ }^{\circ} \mathrm{C}$. The best results were obtained on apple pieces coated with alginate, calcium chloride and acetylated monoglyceride, with a $17.8 \%$ weight loss, whereas the control sample showed the greatest weight loss (31.4\%). These results are in agreement with the present work, because the control sample showed higher weight loss than samples coated with protein isolate croaker and MMT.

Table 1. Effect of CPI coating with and without the MMT on the weight loss (\%) of Fresh-Cut apples stored at 5 $\pm 1{ }^{\circ} \mathrm{C}$ during 12 days

\begin{tabular}{|c|c|c|c|}
\hline \multirow{2}{*}{ Time (days) } & \multicolumn{3}{|l|}{ Treatments } \\
\hline & $\mathrm{T} 1$ & $\mathrm{~T} 2$ & T3 \\
\hline 1 & $0.52 \pm 0.06^{\mathrm{fA}}$ & $0.61 \pm 0.03^{\mathrm{fA}}$ & $0.55 \pm 0.02^{\mathrm{fA}}$ \\
\hline 3 & $2.10 \pm 0.10^{\mathrm{eA}}$ & $1.52 \pm 0.08^{\mathrm{eB}}$ & $0.95 \pm 0.10^{\mathrm{eC}}$ \\
\hline 5 & $3.15 \pm 0.12^{\mathrm{dA}}$ & $2.60 \pm 0.15^{\mathrm{dB}}$ & $1.50 \pm 0.15^{\mathrm{dC}}$ \\
\hline 7 & $4.70 \pm 0.16^{\mathrm{cA}}$ & $3.80 \pm 0.08^{\mathrm{cB}}$ & $2.80 \pm 0.12^{\mathrm{cC}}$ \\
\hline 9 & $5.52 \pm 0.21^{\mathrm{bA}}$ & $4.50 \pm 0.13^{\mathrm{bB}}$ & $3.60 \pm 0.09^{\mathrm{bC}}$ \\
\hline 12 & $8.20 \pm 0.11^{\mathrm{aA}}$ & $5.70 \pm 0.10^{\mathrm{aB}}$ & $4.20 \pm 0.17^{\mathrm{aC}}$ \\
\hline
\end{tabular}

Means followed by the same letter in the column and capital letter in the row did not differ by Tukey's test $(P<$ 0.05). (T1) control, (T2) Fresh-Cut apple coated with pure CPI (T3) Fresh-Cut apple coated with CPI with the addition of MMT. 
Studies by Qi, Hu, Jiang and Tian (2011) demonstrated that the use of chitosan applied as coatings of minimally processed apple pieces reached $15 \%$ weight loss during storage. These results are not in agreement with the results found in this study, therefore, the use of croaker protein isolate along with MMT appeared to be effective against weight loss of pieces of minimally processed apples. Low values of weight loss observed in this study were due to the croaker protein isolate and MMT being able to form a water loss barrier causing a high relative humidity around the fruit, thus reducing the rate of moisture to the outside.

\subsubsection{Firmess}

Table 2 shows the values of firmness $(\mathrm{N})$ in samples of minimally processed apples using different coatings.

From Table 2, we can observe that from the first day of storage a significant difference among treatments was observed. Over the storage days, a decrease in the values of firmness was observed, with the control treatment (T1) presenting high decrease in firmness until the seventh day of storage (17.35). After this period, there was an increase in firmness. This increase in firmness was caused by partial dehydration in the surface, leading to a more abrasive surface (Gorny, Cifuentes, Hess-Pierce, \& Kader, 2000).

Rojas-Grau, Tapia \& Martínbelloso (2008) evaluated the strength of samples of minimally processed apples, coated with alginate and gellan. According to the results, calcium chloride promoted a link between polymer chains, thereby reducing the loss of firmness. Similar effect was observed in this study when croaker protein isolate and MMT were used as coatings on minimally processed apples.

Table 2. Effect of the CPI coating with and without the MMT on the firmness (N) of Fresh-Cut apples stored at 5 $\pm 1{ }^{\circ} \mathrm{C}$ during storage period (12 days)

\begin{tabular}{llll}
\hline \multirow{2}{*}{ Time (days) } & \multicolumn{3}{l}{ Treatments } \\
\cline { 2 - 4 } & T1 & T2 \\
\hline 1 & $30.68 \pm 1.19^{\mathrm{aB}}$ & $33.41 \pm 1.31^{\mathrm{aAB}}$ & $34.72 \pm 2.11^{\mathrm{aA}}$ \\
3 & $27.56 \pm 2.24^{\mathrm{abB}}$ & $33.09 \pm 2.06^{\mathrm{aA}}$ & $34.12 \pm 1.09^{\mathrm{aA}}$ \\
5 & $24.12 \pm 0.57^{\mathrm{bcC}}$ & $30.12 \pm 1.05^{\mathrm{abB}}$ & $32.79 \pm 0.86^{\mathrm{abA}}$ \\
7 & $17.35 \pm 2.51^{\mathrm{eB}}$ & $27.58 \pm 0.72^{\mathrm{bA}}$ & $30.07 \pm 1.81^{\mathrm{bcA}}$ \\
9 & $19.84 \pm 0.17^{\mathrm{deB}}$ & $25.81 \pm 1.24^{\mathrm{bA}}$ & $27.14 \pm 0.77^{\mathrm{cdA}}$ \\
12 & $22.32 \pm 0.45^{\mathrm{cdAB}}$ & $20.19 \pm 2.56^{\mathrm{cB}}$ & $25.39 \pm 1.07^{\mathrm{dA}}$ \\
\hline
\end{tabular}

Means followed by the same letter in the column and capital letter in the row did not differ by Tukey's test $(P<$ 0.05). (T1) control, (T2) Fresh-Cut apple coated with pure CPI (T3) Fresh-Cut apple coated with CPI with the addition of MMT.

Xiao, Luo, Luo and Wang (2011) demonstrated that the use of chitosan and chitosan corboximetil helped to maintain firmness of the pieces of pears during 10 days when stored at $4{ }^{\circ} \mathrm{C}$, and the use of these additives caused a steady increase of $0.25 \mathrm{~N}$ (day 0 ) to $31.3 \mathrm{~N}$ (day 10). These authors attribute this increase in dehydration of the fruit surface, which led to the hardening of the parts of the fruit, thus increasing resistance that resulted in higher firmness measurements. The results obtained by these authors are not in agreement with the results of this study because when croaker protein isolate was added along with MMT drying of the surface of the pieces of apples was not observed.

\subsubsection{Color}

Figure 1 shows the brightness values for the samples of minimally processed apples using different coatings.

Brightness values $\left(\mathrm{L}^{*}\right)$ decreased to the last day of storage for all treatments. Treatment $\mathrm{T} 1$ presented the highest browning $(17.73 \%)$ when compared with the other samples with croaker protein isolate (CPI) T2 $(12.79 \%)$ and T3 (8.53\%).

The brightness results are in accordance with the results obtained by Perez-Gago, Serra and Del-Río (2006), who studied the effect of film-based whey protein on the color changes of minimally processed apples and concluded that the treatments that incorporated protein-based films showed greater inhibition of enzymatic browning. 


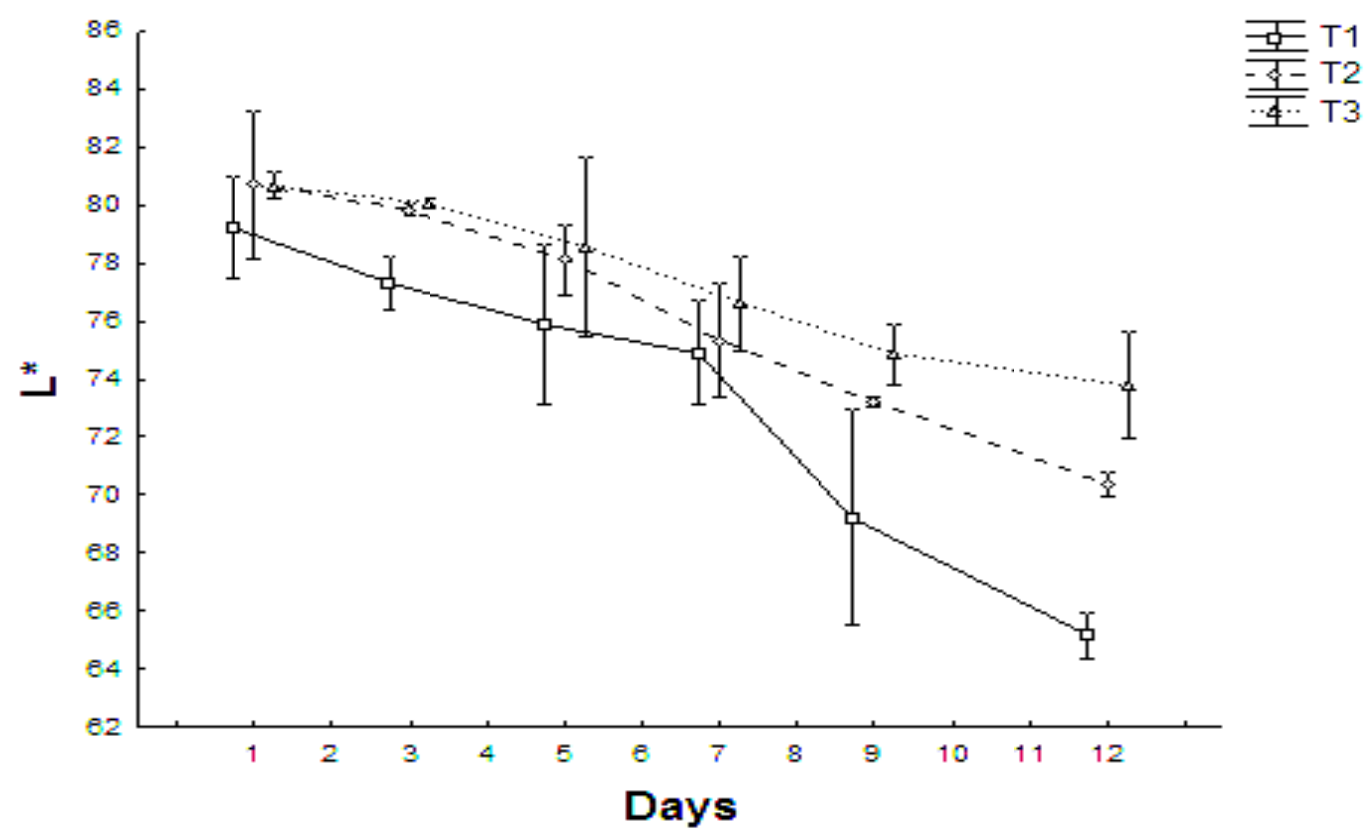

Figure 1. Effect of CPI coating with and without the MMT on the lightness $\left(\mathrm{L}^{*}\right)$ of Fresh-Cut apples stored at 5 $\pm 1{ }^{\circ} \mathrm{C}$ during storage period (12 days)

(T1) control, (T2) Fresh-Cut apples coated with pure CPI (T3) Fresh-Cut apple coated with CPI with the addition of MMT.

Figure 2 shows the values for Chroma $\mathrm{a}^{*}$ and samples of minimally processed apples using different coatings.

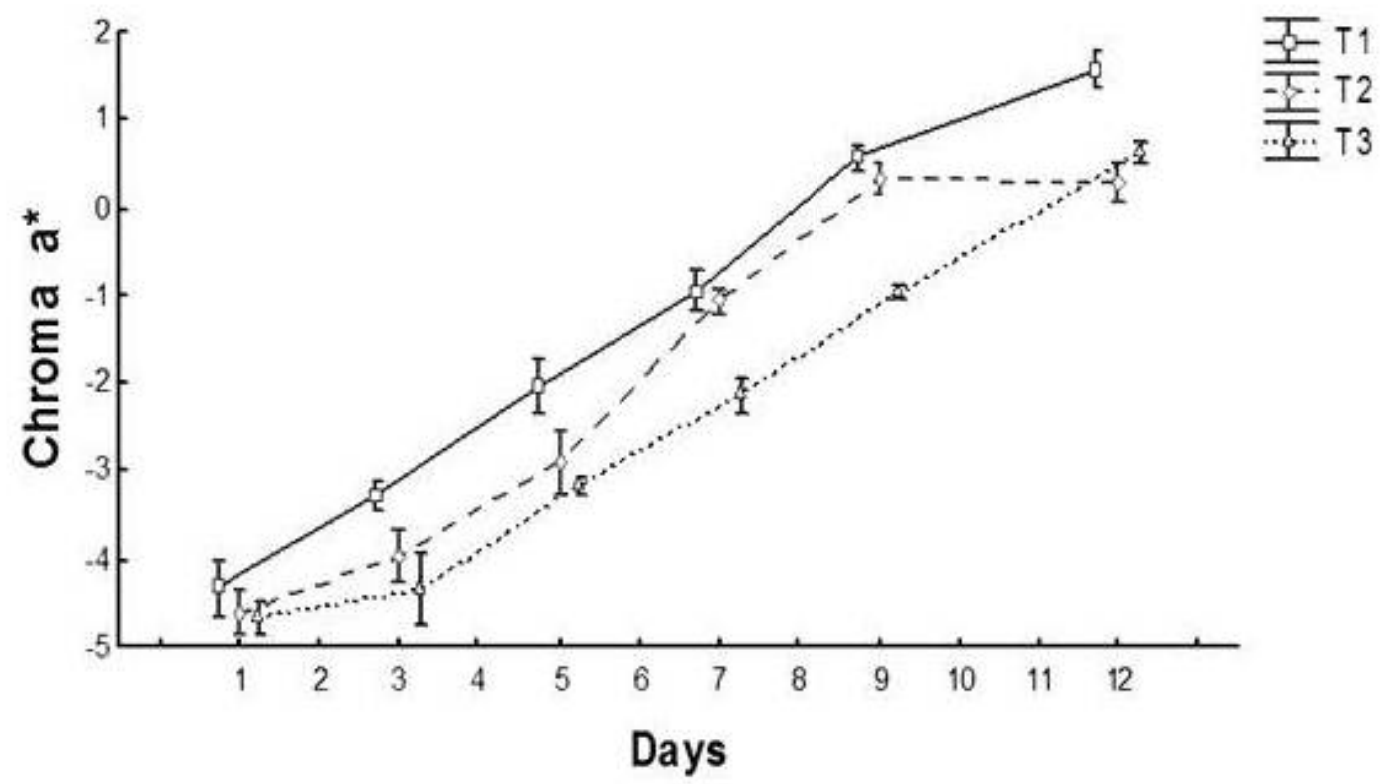

Figure 2. Effect of CPI coating with and without the MMT on the Chroma $\mathrm{a}^{*}$ of Fresh-Cut apples stored at $5 \pm 1$ ${ }^{\circ} \mathrm{C}$ during storage period (12 days)

(T1) control, (T2) Fresh-Cut apples coated with pure CPI (T3) Fresh-Cut apples coated with CPI with the addition of MMT. 
As it can be seen in Figure 2, the values of Chroma a* increased over the days of storage, whereas the control treatment (T1) differed significantly from the other treatments in the 12 days of storage, presenting the highest oxidative browning. Treatment $\mathrm{T} 3$ showed the lowest oxidative browning during storage.

A study by Fontes, Sarmento, Spoto and Dias (2008) demonstrated that the use of starch, dextrin and sodium alginate were effective to maintain the values of Chroma a* lower than the control sample during 13 days of storage. These results agree with the present work, since the use of croaker protein isolate along with MMT as coatings were efficient to keep the pieces of apples with a more pleasing color for longer when compared with the control sample.

Figure 3 shows the Chroma $b^{*}$ values for samples of minimally processed apples using different coatings.

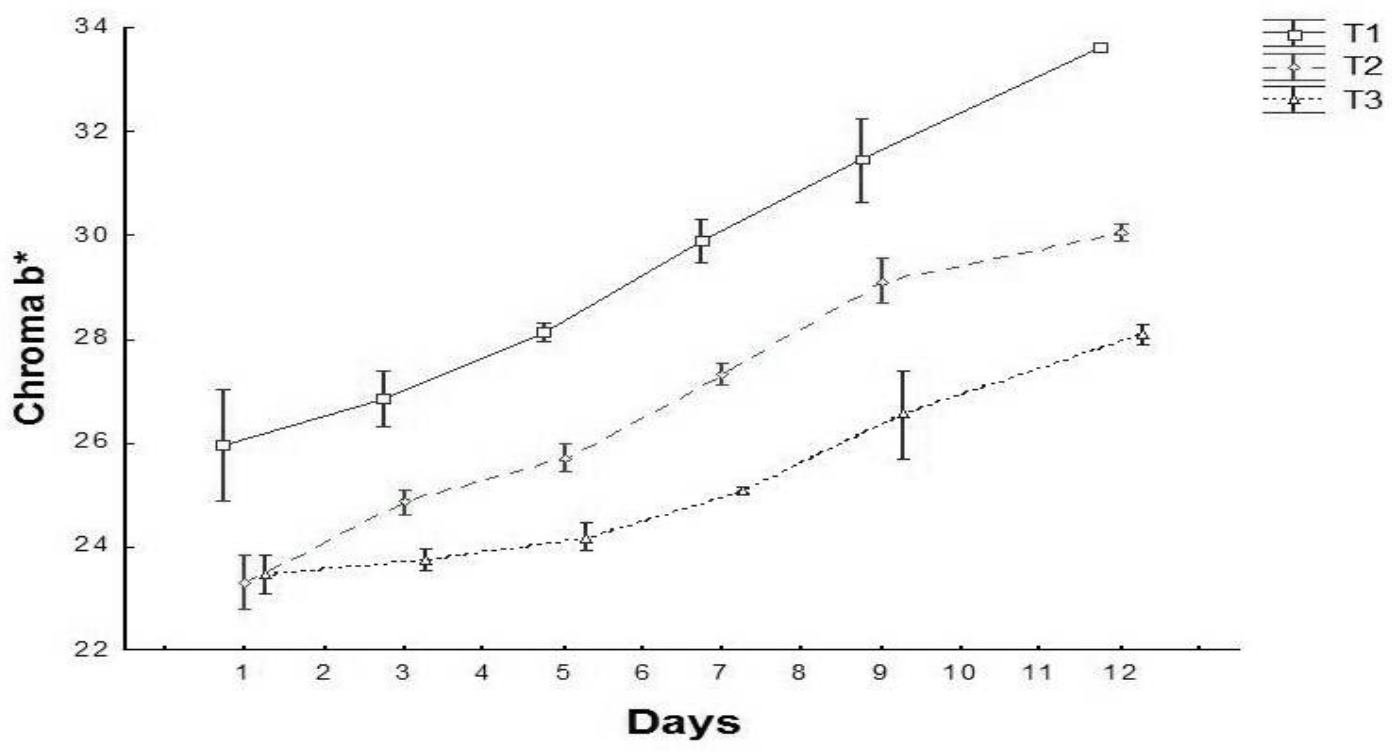

Figure 3. Effect of CPI coating with and without the MMT on the Chroma $b^{*}$ of Fresh-Cut apples stored at $5 \pm 1$ ${ }^{\circ} \mathrm{C}$ during 12 days

(T1) control, (T2) Fresh-Cut apples coated with pure CPI (T3) Fresh-Cut apples coated with CPI with the addition of MMT.

The values of Chroma $b^{*}$ increased for all treatments and since the first day of storage significant difference was observed in all treatments, this increase indicates a trend towards a more yellowish color and therefore greater oxidative browning. Treatments T2 and T3 presented the lowest browning when compared with T1.

The increase in Chroma $b^{*}$ values for the control (T1) agrees with the results obtained by Fontes et al. (2008), who also had higher values of Chroma $b^{*}$ in the control treatment compared to the other treatments. When these same authors used the application of the preservative solution in combination with different coatings, they found values between 33.1 and 30.5, and these values were higher than those found in this work $(30.05-28.09)$ for T2 and $\mathrm{T} 3$ respectively, showing that the use of croaker protein isolate and MMT were really effective in inhibiting the oxidative browning.

\section{$3.1 .4 \mathrm{pH}$}

Table 3 presents the $\mathrm{pH}$ values found in minimally processed apples stored at $5 \pm 1{ }^{\circ} \mathrm{C}$ for a period of 12 days. 
Table 3. Effect of CPI coating with and without the MMT on the pH of Fresh-Cut apples stored at $5 \pm 1{ }^{\circ} \mathrm{C}$ during storage period (12 days)

\begin{tabular}{llll}
\hline \multirow{2}{*}{ Time (days) } & Treatments & \\
\cline { 2 - 4 } & $\mathrm{T} 1$ & $\mathrm{~T} 2$ & $\mathrm{~T} 3$ \\
\hline 1 & $4.98 \pm 0.03^{\mathrm{aA}}$ & $4.79 \pm 0.05^{\mathrm{aB}}$ & $4.77 \pm 0.04^{\mathrm{aB}}$ \\
3 & $4.97 \pm 0.05^{\mathrm{aA}}$ & $4.79 \pm 0.02^{\mathrm{aAB}}$ & $4.76 \pm 0.02^{\mathrm{abB}}$ \\
5 & $4.73 \pm 0.06^{\mathrm{bcA}}$ & $4.72 \pm 0.02^{\mathrm{aA}}$ & $4.69 \pm 0.03^{\mathrm{abA}}$ \\
7 & $4.66 \pm 0.03^{\mathrm{cAB}}$ & $4.57 \pm 0.03^{\mathrm{bC}}$ & $4.61 \pm 0.04^{\mathrm{abcBC}}$ \\
9 & $4.55 \pm 0.05^{\mathrm{dAB}}$ & $4.46 \pm 0.04^{\mathrm{cB}}$ & $4.59 \pm 0.01^{\mathrm{abcA}}$ \\
12 & $4.70 \pm 0.02^{\mathrm{bcA}}$ & $4.40 \pm 0.01^{\mathrm{cdB}}$ & $4.53 \pm 0.02^{\mathrm{bcC}}$
\end{tabular}

Means followed by the same letter in the column and capital letter in the row did not differ by Tukey's test $(P<$ 0.05). (T1) control, (T2) Fresh-Cut apple coated with pure CPI (T3) Fresh-Cut apple coated with CPI with the addition of MMT.

Acidity is a factor of great importance to the flavor and aroma of the fruit (Cortez-Vega, Becerra-Prado, Soares, \& Fonseca, 2008). The $\mathrm{pH}$ influences the oxidative browning of plant tissues, with the decrease in its value causing a reduction in the rate of browning of the fruit (Freitas, Cortez-Vega, Pizato, Prentice-Hernández, \& Borges, 2013).

There was a tendency of $\mathrm{pH}$ reduction of the minimally processed apple samples subjected to different treatments. A marked decrease in $\mathrm{pH}$ of the control sample (T1) was observed until the ninth day of storage, and then there was an increase in $\mathrm{pH}$ value. At the end of storage, the $\mathrm{pH}$ of the samples submitted to the control treatment (T1) was significantly higher than the others, and this treatment had a $\mathrm{pH}$ decrease of $5.62 \%$. Treatment $\mathrm{T} 3$ presented the lowest reduction in $\mathrm{pH}(5.03 \%)$, and after the 12 days of storage, all treatment showed significant difference between each other. The results found in this study agree with Cortez-Vega et al. (2008), who also found smaller $\mathrm{pH}$ values in pieces of apples treated with sodium metabisulfite in all evaluated days, while the highest $\mathrm{pH}$ values were observed in the control sample.

Rocculi, Nobile, Romani, Baiano and Dalla Rosa (2004) found no significant difference in the change in pH on apples treated with a solution containing citric acid, ascorbic acid and calcium chloride when stored at $4{ }^{\circ} \mathrm{C}$ for 12 days. These results differ from those in the present work, since significant differences were found between all treatments in samples of minimally processed apples in the 12 days of storage.

\subsection{Microbiological Analysis}

In Brazil, there is no specific legislation for minimally processed fruits and vegetables with the tolerated limit counts. However, there is legislation for fresh fruit, in natura, prepared (peeled or selected or fractional) sanitized, chilled or frozen, which stipulates maximum values of Escherichia coli $<10^{2} \mathrm{CFU} \mathrm{g}^{-1}$ and absence of Salmonella in $25 \mathrm{~g}$ of sample (BRASIL, 2001).

The presence of Escherichia coli $\left(<10^{2} \mathrm{CFU}\right.$ g-1) and Salmonella in samples of minimally processed apples was not detected, confirming the effectiveness of cleaning and the action of organic chlorine to disinfect the samples.

Figure 4 shows the values found for psychrotrophic microorganisms, molds and yeast for samples of minimally processed apples using different coatings stored for 12 days at $5 \pm 1{ }^{\circ} \mathrm{C}$.

As we can see, the growth of psychrotrophic microorganisms (Figure 4 (a)) increased over the days of storage. It was possible to observe that there was a significant difference in relation to T1 during all the days analyzed. 

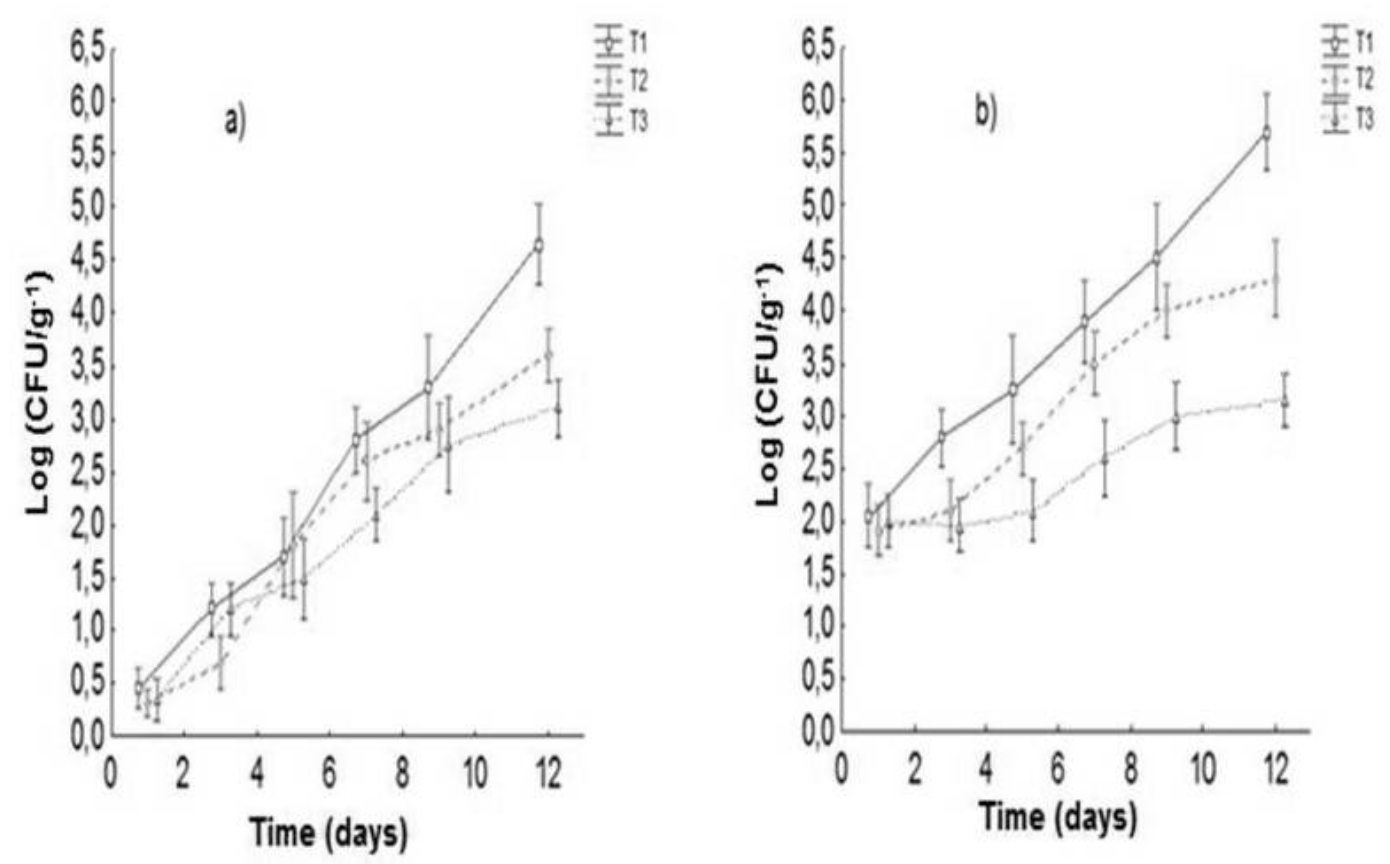

Figure 4. Growth of psychrotrophic microorganisms, yeast and mold in fresh-cut apples stored at $5 \pm 1{ }^{\circ} \mathrm{C}$ for 12 days. Where: a) psychrotrophic microorganisms b) yeast and mold microorganisms. (T1) control, (T2) Fresh-Cut apples coated with pure CPI, (T3) Fresh-Cut apples coated with CPI with the addition of MMT

Between the fifth and twelfth day of storage there was no significant difference among all evaluated treatments with treatment $\mathrm{T} 3$ showing the lowest growth in relation to psychrotrophic microorganisms.

In a study, Rojas-Grau et al. (2008) showed that coatings based on alginate and gellan with N-acetylcysteine applied in minimally processed apples influenced the reduction of psychrotrophic count. After 3 weeks of storage the samples did not exceed $10^{5} \mathrm{CFU} \mathrm{g}^{-1}$, whereas the control sample showed $10^{8} \mathrm{CFU} \mathrm{g}^{-1}$. These results are in agreement with those in present work which also showed that the use of coatings based on croaker protein isolate and MMT were effective in slowing the growth of psychrotrophic microorganisms and at the end of 12 days of storage treatment $\mathrm{T} 3$ did not exceed $10^{4} \mathrm{CFU} \mathrm{g}^{-1}$.

Lee, Park, Lee and Choi (2003) evaluated the psychrotrophic microorganism count in minimally processed apples treated with carrageenan and whey protein concentrate added with a preservative solution. Their results show that the coatings were effective in reducing the count of these microorganisms. After 14 days of storage, the count did not exceed $10^{6} \mathrm{CFU} \mathrm{g}^{-1}$ for psychrotrophic microorganisms. The microbiological standards for nonthermal processed foods according to IFST (1999) considers this value $\left(10^{6} \mathrm{CFU} \mathrm{\textrm {g } ^ { - 1 }}\right)$ as the maximum acceptance for products based on fruits during the study of shelf life.

It may also be noted that all the treatments evaluated showed similar behavior, that is, over the storage days the count of yeasts and molds in samples of minimally processed apples stored for 12 days at $5 \pm 1{ }^{\circ} \mathrm{C}$ increased. A significant difference was observed among all treatments in the 12 days of storage, and treatment $\mathrm{T} 3$ showed the lowest count of yeasts and molds during this period. All treatments showed initial counts below $10^{1} \mathrm{CFU} \mathrm{g}^{-1}$. These results are in agreement with the results found by Pizato, Cortez-Vega, Prentice-Hernández, \& Borges (2013b), who found initial values of $0.52 \log C F U ~ g^{-1}$ for yeasts and molds in samples of minimally processed apples. These same authors also found yeast and mold counts below $10^{5} \mathrm{CFU} \mathrm{g}^{-1}$ in 15 days of storage at $4 \pm$ $1{ }^{\circ} \mathrm{C}$ when tara gum was used as a coating of the apples pieces.

\section{Conclusion}

It can be concluded that the different coatings used in this study were effective in preserving minimally processed apples compared to the control sample. From all the treatments evaluated, the coating containing croaker protein isolate showed the best results, being able to reduce the mass loss, decrease enzymatic browning, provide maintenance of firmness and low microbial count during storage. 


\section{References}

AOAC. (2000). Association of Official Analytical Chemists. Official methods of analysis (16th ed). Washington: Association of Official Analytical Chemists.

APHA. (2001). American Public Health Association. Compendium of methods for the microbiological examination of foods (p. 676). Washington, D.C.

BRASIL. (2001). Ministério da Saúde. Resolução RDC n ${ }^{\circ} 12$, de 02 de janeiro de 2001. Aprova o Regulamento Técnico sobre padrões microbiológicos para alimentos. Diário Oficial da República Federativa do Brasil. Brasília, DF, 10 jan. Seção 1, 46-53.

Carvalho, A. V., \& Lima, L. C. O. (2002). Qualidade de kiwis minimamente processados e submetidos a tratamento com ácido ascórbico, ácido cítrico e cloreto de cálcio. Pesquisa Agropecuária Brasileira, 37, 679-685. http://dx.doi.org/10.1590/S0100-204X2002000500013

Chiumarelli, M., Pereira, L. M., Ferrari, C. C., Sarantópoulos, C. I. G. L., \& Hubinger, M. D. (2010). Cassava starch coating and citric acid to preserve quality parameters of fresh-cut. Journal of Food Science, 75, 297-304. http://dx.doi.org/10.1111/j.1750-3841.2010.01636.x

Cortez-Vega, W. R., Becerra-Prado, A. M., Soares, J. M., \& Fonseca, G. G (2008). Effect of L-Ascorbic Acid and Sodium Metabisulfite in the Inhibition of the Enzymatic Browning of Minimally Processed Apple. International Journal of Agricultural Research, 3, 196-201. http://dx.10.3923/ijar.2008.196.201

Fontes, L. C. B., Sarmento, S. B. S. S., Spoto, M. H. F. \& Dias, C. T. S. (2008). Conservação de maçã minimamente processada com o uso de películas comestíveis. Ciência e Tecnologia de Alimentos, 28, 872-880. http://dx.doi.org/10.1590/S0101-20612008000400017

Freitas, I. R., Cortez-Vega, W. R., Pizato, S., Prentice-Hernández, C., \& Borges, C. D. (2013). Xanthan Gum as a Carrier of Preservative Agents and Calcium Chloride Applied on Fresh-Cut Apple. Journal of Food Safety, 33, 39-48. http://dx.doi.org/10.1111/jfs. 12044

Freitas, I. R., Gautério, G. V., Rios, D. G., \& Prentice, C. (2011). Functionality of protein isolates from argentine anchovy (Engraulis anchoita) residue obtained using ph shift processing. Journal Food Science Engineering, 1, 374-378.

Gorny, J. R., Cifuentes, R. A., Hess-Pierce, B., \& Kader, A. A. (2000). Quality changes in fresh-cut pear slices as affected by cultivar, ripeness stage, fruit size, and storage regime. Journal of Food Science, 65, 541-544. http://dx.doi.org/10.1111/j.1365-2621.2000.tb16044.x

IFST - Institute of Food Science and Technology. (1999). Development and use of microbiological criteria for foods. London, p.76.

Krochta, J. M., \& Mulder-Johnston, C. (1997). Edible and biodegradable polymer films: challenges and opportunities. Food Technology, 51, 61-74.

Lee, J. Y., Park, H. J., Lee, C. Y., \& Choi, W. Y. (2003). Extending shelf life of minimally processed apples with edible coatings and antibrowning agents. LWT-Food Science and Technology, 36, 323-329. http://dx.doi.org/10.1016/S0023-6438(03)00014-8

Li, W. L., Li, X. H., Fan, X., Tang, Y., \& Yun, J. (2012). Response of antioxidant activity and sensory quality in fresh-cut pear as affected by high $\mathrm{O}_{2}$ active packaging in comparison with low $\mathrm{O}_{2}$ packaging. Food Science and Technology International, 18, 197-205. http://dx.doi.org/10.1177/1082013211415147

Nolsoe, H., \& Undeland, I. (2009). The acid and alkaline solubilization process for the isolation of muscle proteins. Food Bioprocess and Technology, 2, 1-27. http://dx.doi.org/10.1007/s11947-008-0088-4

Olivas, G. I., Mattinson, D. S., \& Barbosa-Cánovas, G. V. (2007). Alginate coatings for preservation of minimally processed "Gala" apples. Postharvest Biology and Technology, 45, 89-96. http://dx.doi.org/10.1016/j

Perez-Gago, M. B.; Serra, M., \& Del-Río, M. (2006). Color changes of fresh-cut apples coated with why protein concentrate-based edible coatings. Postharvest Biology and Technology, 39, 84-92. http://dx.doi.org/10.1016/j.postharvbio.2005.08.002

Pizato, S., Cortez-Vega, W. R., Souza, J. T. A., Prentice-Hernández, C., \& Borges, C. D. (2013a). Effects of different edible coatings in physical, chemical and microbiological characteristics of minimally processed peaches (prunus persica 1. batsch). Journal of Food Safety, 33, 30-39. http://dx.doi.org/10.1111/jfs.12020 
Pizato, S., Cortez-Vega, W, R., Prentice-Hernández, C., \& Borges, C, D. (2013b). Effect of applying different edible coatings on conservation of minimally processed 'Royal Gala' apples. Semina: Ciências Agrárias, 34, 253-264. http://dx.doi.org/10.5433/1679-0359.2013v34n1p253

Qi, H., Hu, W., Jiang, A., \& Tian, M. (2011). Extending shelf life of fresh-cut 'Fuji' apples with chitosan-coatings. Innovative Food Science \& Emerging Technologies, 12, 62-66. http://dx.doi.org/10.1016/j.ifset.2010.11.001

Rizzon, L. A., Bernadi, J., \& Miele, A. (2005). Características analíticas dos sucos de maçã Gala, Golden Delicius e Fuji. Ciência e Tecnologia de Alimentos, 25, 750-756. http://dx.doi.org/10.1590/S0101-20612005000400020

Rocculi, P., Nobile, M. A., Romani, S., Baiano, A., \& Dalla Rosa, M. (2006). Use of a simple mathematical model to evaluate dipping and MAP effects on aerobic respiration of minimally processed apples. Journal of Food Engineeringv, 7, 334-340. http://dx.doi.org/10.1016/j.jfoodeng.2005.05.034

Rojas-Graü, M. A., Tapia, M. S., \& Martínbelloso, O. (2008). Using polysaccharide-based edible coatings to maintain quality of fresh-cut Fuji apples. LWT - Food Science and Techonology, 41, 139-147. http://dx.doi.org/10.1016/j.lwt.2007.01.009

Vilas Boas, E. V. B., Reis, C. M. F., Melo, A. A., \& Martins, B. (2009). Uso de misturas químicas para manutenção da firmeza de banana 'prata' minimamente processada. Ciência e Agrotecnologia, 33, 237-244. http://dx.doi.org/10.1590/S1413-70542009000100033

Xiao, Z., Luo, Y., Luo, Y., \& Wang, Q. (2011). Combined effects of sodium chlorite dip treatment and chitosan coatings on the quality of fresh-cut d'Anjou pears. Postharvest Biology and Technology, 62, 31-326. $\mathrm{http}: / / \mathrm{dx}$.doi.org/10.1016/j.postharvbio.2011.07.007

\section{Copyrights}

Copyright for this article is retained by the author(s), with first publication rights granted to the journal.

This is an open-access article distributed under the terms and conditions of the Creative Commons Attribution license (http://creativecommons.org/licenses/by/3.0/). 